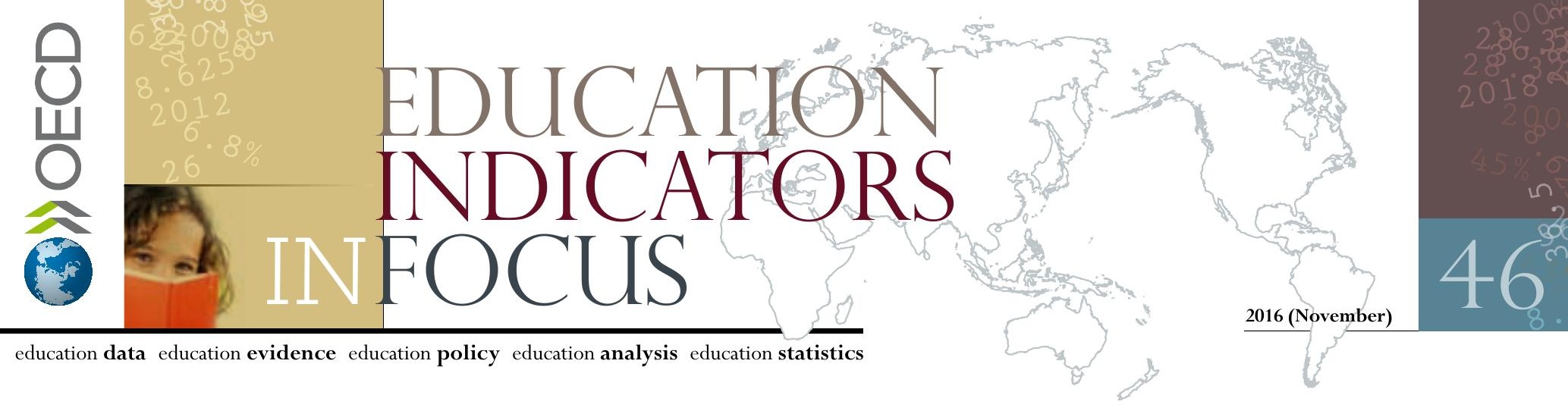

\title{
What influences spending on education?
}

- Spending on teaching staff makes up the largest share of education expenditure, and this depends on at least four factors: students' instruction hours, teachers' teaching hours, class size and teachers' salaries. These four factors combined determine the level of teachers' salary cost per student.

- Higher levels of education tend to have higher teachers' salary costs per student. This is mostly due to increases in both teacher salaries and instruction time, and shorter teaching hours.

- Similar levels of teachers' salary cost per student may mask very different policies. Evidence shows that, among high-income countries, prioritising teacher salaries over class size tends to lead to better student outcomes.

The challenge of providing more and better education with tightening public budgets has made governments increasingly interested in the efficient allocation of education resources. Results from the OECD Programme for International Student Assessment (PISA) show that, among countries with a comparatively high gross domestic product (GDP) per capita, the amount spent on education is less important than how those resources are used.

The salary cost of teachers per student is one way of analysing and comparing different countries' policies regarding expenditure on education. This measure, which takes into account teachers' salaries, class size, teachers' teaching hours and students' instruction time, covers the main source of expenditure on education in all OECD countries. This briefing highlights the trade-offs between these four factors and how they influence the management of education resources. Given a fixed education budget, for example, higher teachers' salaries may be balanced by more teaching time for teachers, less instruction time for student, or larger class sizes.

\section{Calculating teachers'salary costs across OECD countries}

The four factors used to calculate teachers' salary costs help define a country's educational system (Box 1). The challenge countries face is to find the right balance between these factors, taking into account their costs, in order to ensure high-quality education and sustainable education budgets.

$$
\text { Salary cost of teachers per student }=\frac{\text { Salaries }^{1} * \text { Instruction time }}{\text { Teaching time }{ }^{*} \text { Class size }{ }^{2}}
$$

${ }^{1}$ Teachers' salary used in the calculation is the statutory salary of teachers with typical qualifications after 15 years of experience. However, the statutory salary is only one component of teachers' total compensation.

${ }^{2}$ The class size used in the calculation is an estimated class size constructed using the student-teacher ratio, instruction time and teaching time. This estimated measure should therefore be interpreted only as a proxy for class size.

Instruction time: almost all OECD countries have statutory or regulatory requirements that stipulate the minimum number of hours of instruction students must receive. In most OECD countries the statutory instruction time tends not to change significantly from one year to the next.

Teaching time: countries usually regulate the number of hours per year that teachers are formally required to work, divided into teaching and non-teaching activities. Although the categorisation of tasks into teaching and non-teaching may not adequately describe today's teaching roles, the measure of teaching time used in the calculation of the salary cost refers to 
the time teachers actually spend in front of the class, as opposed to performing such tasks as preparing lessons and correcting work. As with instruction time, teaching time varies significantly across countries, but changes little from year to year.

Class size: because it may affect how much time and attention a teacher can give to individual students, class size receives a lot of attention from policy makers and the general public. Unlike teaching and instruction time, class sizes are often the object of reforms and, after teachers' salaries, have the greatest influence on overall teachers' salary costs per student.

Teachers' salaries: this is the largest single cost in formal education and the factor with the largest impact on the salary cost of teachers. Like class size, this factor is often changed through regulations or education reforms. Since compensation is important to attract and retain high-quality teachers, policy makers must carefully consider teachers' salaries as they try to ensure quality education.

Table 1. OECD average, maximum and minimum values for the four factors, by level of education (2014)

\begin{tabular}{|c|c|c|c|}
\hline & PRIMARY & LOWER SECONDARY & UPPER SECONDARY \\
\hline $\begin{array}{l}\text { Teachers' } \\
\text { salaries }^{1}\end{array}$ & $\begin{array}{l}\text { OECD average: USD } 42675 \\
\text { Max: USD } 65543 \text { (Canada) } \\
\text { Min: USD } 16663 \text { (Slovak Republic) }\end{array}$ & $\begin{array}{l}\text { OECD average: USD } 44407 \\
\text { Max: USD } 69431 \text { (Germany) } \\
\text { Min: USD } 16663 \text { (Slovak Republic) }\end{array}$ & $\begin{array}{l}\text { OECD average: USD } 46 \mathbf{3 7 9} \\
\text { Max: USD } 73632 \text { (Germany) } \\
\text { Min: USD } 16663 \text { (Slovak Republic) }\end{array}$ \\
\hline Class size & $\begin{array}{l}\text { OECD average: } 15 \text { students } \\
\text { Max: } 28 \text { (Mexico) } \\
\text { Min: } 10 \text { (Luxembourg) }\end{array}$ & $\begin{array}{l}\text { OECD average: } 17 \text { students } \\
\text { Max: } 40 \text { (Mexico) } \\
\text { Min: } 10 \text { (Slovenia) }\end{array}$ & $\begin{array}{l}\text { OECD average: } 19 \text { students } \\
\text { Max: } 26 \text { (Turkey) } \\
\text { Min: } 11 \text { (Luxembourg) }\end{array}$ \\
\hline Teaching time & $\begin{array}{l}\text { OECD average: } 771 \text { hours } \\
\text { Max: } 1146 \text { (Chile) } \\
\text { Min: } 569 \text { (Greece) }\end{array}$ & $\begin{array}{l}\text { OECD average: } 692 \text { hours } \\
\text { Max: } 1146 \text { (Chile) } \\
\text { Min: } 459 \text { (Greece) }\end{array}$ & $\begin{array}{l}\text { OECD average: } 641 \text { hours } \\
\text { Max: } 1146 \text { (Chile) } \\
\text { Min: } 386 \text { (Denmark) }\end{array}$ \\
\hline Instruction time & $\begin{array}{l}\text { OECD average: } 788 \text { hours } \\
\text { Max: } 1049 \text { (Chile) } \\
\text { Min: } 592 \text { (Latvia) }\end{array}$ & $\begin{array}{l}\text { OECD average: } 902 \text { hours } \\
\text { Max: } 1167 \text { (Mexico) } \\
\text { Min: } 710 \text { (Hungary) }\end{array}$ & $\begin{array}{l}\text { OECD average: } 929 \text { hours } \\
\text { Max: } 1165 \text { (Chile) } \\
\text { Min: } 805 \text { (Portugal) }\end{array}$ \\
\hline $\begin{array}{l}\text { Annual teachers' } \\
\text { salary cost per } \\
\text { student }{ }^{1}\end{array}$ & $\begin{array}{l}\text { OECD average: USD } 2832 \\
\text { Max: USD } 4542 \text { (Denmark) } \\
\text { Min: USD } 969 \text { (Slovak Republic) }\end{array}$ & $\begin{array}{l}\text { OECD average: USD } 3 \mathbf{3 8 9} \\
\text { Max: USD } 5379 \text { (Austria) } \\
\text { Min: USD } 1000 \text { (Mexico) }\end{array}$ & $\begin{array}{l}\text { OECD average: USD } 3776 \\
\text { Max: USD } 6166 \text { (Belgium [Fl.]) } \\
\text { Min: USD } 1205 \text { (Slovak Republic) }\end{array}$ \\
\hline
\end{tabular}

1. Luxembourg is an outlier and has been removed from the comparison for teachers' salaries and salary cost of teachers in order not to distort the comparability.

Source: OECD (2016), Education at a Glance 2016: OECD Indicators, www.oecd.org/education/education-at-a-glance-19991487.htm.

On average across OECD countries, the salary cost of teachers per student tends to rise with educational level (Table 1). This general increase is partly due to higher teachers' salaries. In addition, higher educational levels also tend to require more instruction time for students and less teaching time for teachers (giving teachers more time to prepare lessons, grade assignment, etc.). All other things being equal, this means additional teachers and, in turn, an increase in teachers' salary cost per student. Higher levels of education also tend to have larger classes, which reduces salary costs per student, but this decrease is offset by the other three factors.

\section{Countries face trade-offs when allocating resources to education}

Similar overall teachers' salary costs per student can mask very different policies. It is therefore important to analyse how different combinations of policies on the four factors have influenced the salary cost of teachers in each country. Figure 1 shows the contribution of each factor to the difference between countries' salary cost of teachers per student and the OECD average at the lower secondary level. This highlights the trade-offs countries face when deciding how to allocate education resources.

For example, some countries have smaller class sizes, which they pay for with below-average teachers' salaries and instruction time. This is the case in lower secondary education in the Czech Republic, Finland, Greece and Hungary. Countries with smaller class sizes and higher teachers' salaries, such as Germany, may compensate with shorter instruction hours and longer teaching hours.

Other countries have relatively high teachers' salaries and provide teachers with ample time for activities outside of the classroom (shorter teaching time). Both of these policies push the salary cost of teachers up, which they balance with larger classes and shorter instruction time. This is the case in Japan and Korea - although, despite similar 


\section{Figure 1. Contribution of various factors to salary cost of teachers per student in lower secondary education (2014) \\ In public institutions in equivalent USD converted using PPPs}

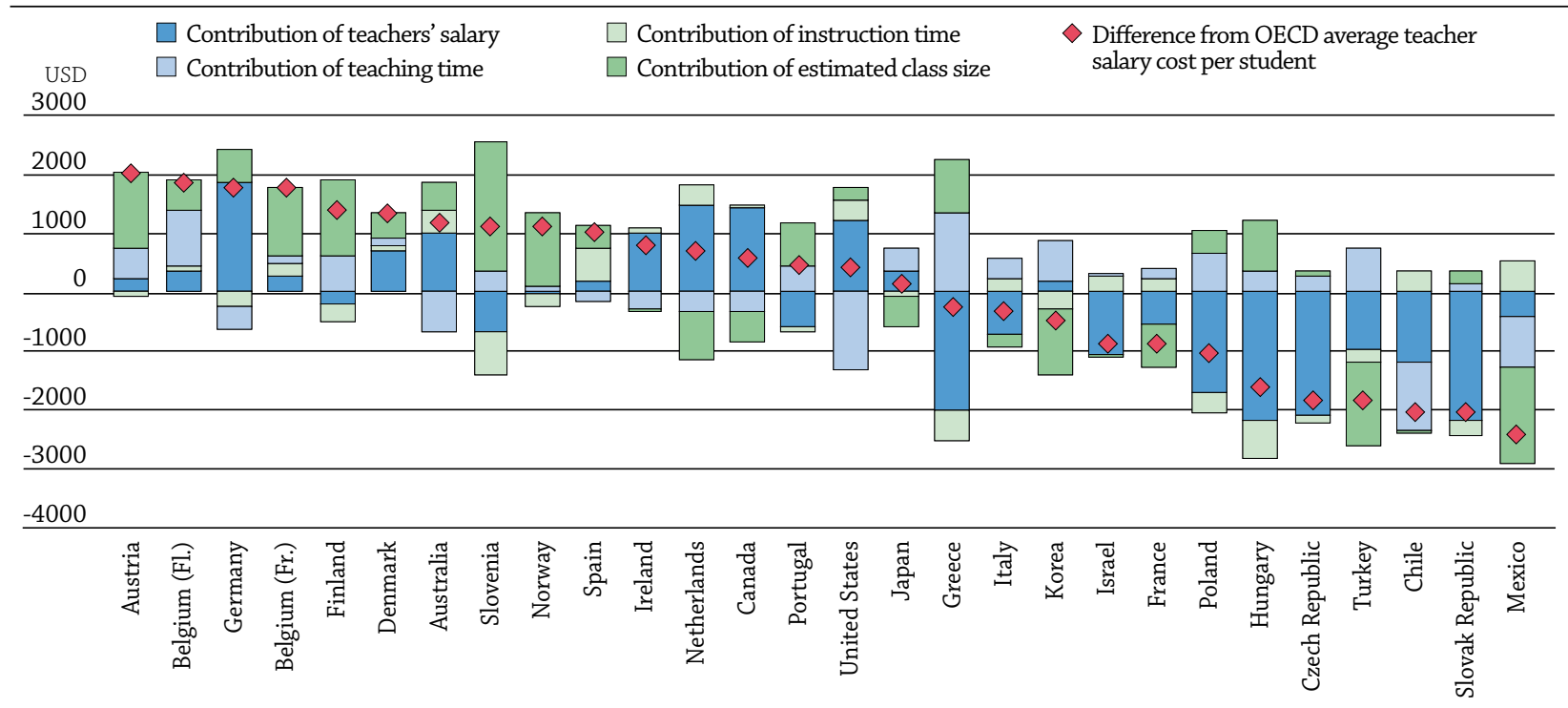

\section{How to read this chart}

This chart shows the contribution (in USD) of the factors influencing the difference between salary cost of teachers per student in the country and the OECD average. For example, in Hungary, the salary cost of teachers per student is USD 1613 lower than the OECD average. This is because Hungary has lower teachers' salaries (- USD 2 168) than the OECD average, below-average instruction time for students (- USD 674), above-average teaching time for teachers (+ USD 384), and above-average estimated class size (+ USD 845).

Note: Luxembourg has been removed from the chart in order to improve comparability.

Countries are ranked in descending order of the difference between the salary cost of teachers per student and the OECD average.

Source: OECD (2016), Education at a Glance 2016: OECD Indicators, www.oecd.org/education/education-at-a-glance-19991487.htm.

policy approaches, these countries have different overall teaching salary costs, with Japan being slightly above the OECD average and Korea below it.

Some countries arrive at similar salary cost levels through very different approaches. In 2014, Australia and Slovenia had very similar levels of salary cost of teachers per student in lower secondary education, both above the OECD average. In Australia, this was the result of the combination of above-average teachers' salaries, instruction time and teaching time and below-average estimated class size. In Slovenia, teachers' salaries and instruction time are below average, but the salary cost per student is pushed up by small estimated class sizes and below-average teaching time.

\section{Which combination of policies is most effective?}

Given that many different policy approaches can result in similar levels of expenditure on education, and salary cost of teachers per student, it is important to assess whether some are more effective than others. Answering this question, however, is far from simple.

There is little consensus among countries on the most effective policies related to instruction time. The organisation of the school day, as well as the methods used for teaching and learning, seem to be more important factors than the actual number of hours spent in school. There is also no relation between instruction time and teaching time in OECD countries, and the wide variation across low- and high-performing countries on both dimensions suggests that these factors alone are not enough to guarantee better student outcomes (OECD, 2014).

Nevertheless, it is still possible to learn from countries' experiences and identify some general patterns of successful strategies. Results from previous editions of PISA show that top-performing countries tend to prioritise teacher quality above all. One important measure to attract and retain quality teachers is through salaries. Among countries and economies with a per capita GDP of over USD 20 000, which includes most OECD countries, there is a positive relation between higher teachers' salaries (relative to national income per capita) and performance in mathematics (OECD, 2013). 


\section{EDUCATION INDICATORS IN FOCUS}

education data education evidence education policy education analysis education statistics

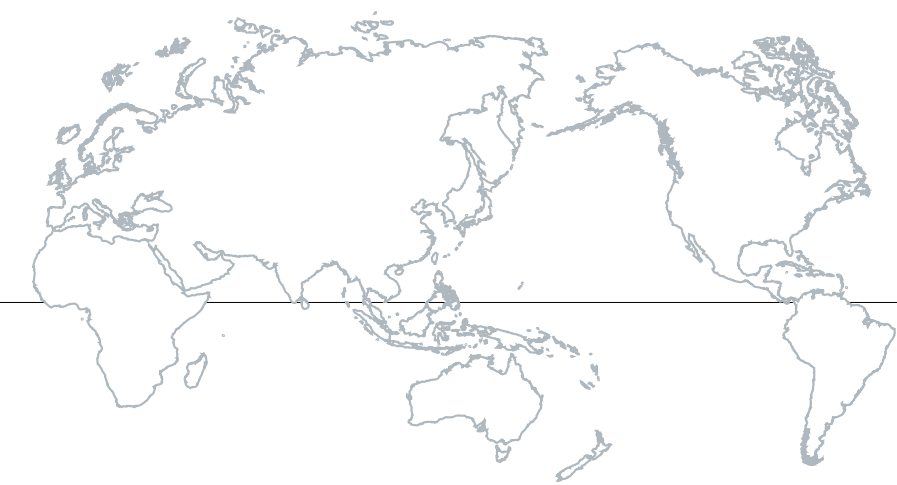

The positive impact of increasing teachers' salaries in such countries holds true even if the trade-off is larger classes. In fact, among the countries and economies participating in PISA, school systems that invest in higher teachers' salaries tend to have larger classes. Japan and Korea, two top performers in PISA, are good examples of countries prioritising salaries over class size. Both countries pay their teachers relatively well and require fewer teaching hours, so that teachers have more time for activities such as preparing lessons, meeting other teachers and tutoring students who are behind. Both countries compensate for these measures with larger class sizes.

However, the extent to which the trade-off between higher teachers' salaries and larger classes should be made depends on national and school circumstances. In less wealthy countries, for example, a host of resources (such as material infrastructure, instructional materials and transportation) may need to be improved before the benefits of investing in human resources for example through higher teachers' salaries are able to take full effect (OECD, 2013).

Moreover, larger class sizes may pose a greater challenge within specific contexts. For example, teachers with a high share of students with behavioural problems and large classes may have to spend too much time keeping order in the classroom and not enough on teaching and learning activities (OECD, 2015). Students considered at risk may also benefit from more personalised teacher attention or more opportunities for student engagement. Although these factors must be considered when making policy decisions, it is still not clear whether reducing class size is the best solution. If larger class sizes free up resources to invest in teacher training to prepare teachers to deal with challenging classrooms better, the trade-off may still be effective.

Finally, it is important to consider that there are several other factors not included in the salary cost of teachers per student that help determine the success of a country's educational system. These include the pedagogical training (on top of any subject-specific training) that teachers are required to complete before entering the profession; the prevalence and quality of teacher development programmes; and even factors that cannot be legislated for, such as society's trust in teachers and teachers' view of their value within society. All of these factors also influence the attractiveness, and therefore the quality, of the teaching profession.

More data and information on this topic is available in Education at a Glance 2016.

The bottom line: Effective allocation of resources is just as important as the size of the education budget. Countries with the same level of educational expenditure can have very different educational policies and priorities. The salary cost of teachers per student highlights some of the most important trade-offs countries face when choosing their own combination of policies. Although there is no one-size-fits-all combination of policies that will guarantee successful student outcomes, the evidence points to the importance of valuing teachers above all.

\section{For more information}

- OECD (2016), Education at a Glance 2016: OECD Indicators, OECD Publishing, Paris, http://dx.doi.org/10.1787/eag-2016-en.

- OECD (2015), Education at a Glance 2015: OECD Indicators, OECD Publishing, Paris, http://dx.doi.org/10.1787/eag-2015-en.

- OECD (2014), "How much time do primary and lower secondary students spend in the classroom?", Education Indicators in Focus, No. 22, OECD Publishing, Paris, http://dx.doi.org/10.1787/5jz44fnl1t6k-en.

- OECD (2013), PISA 2012 Results: What Makes Schools Successful (Volume IV): Resources, Policies and Practices, PISA, OECD Publishing, Paris, http:// dx.doi.org/10.1787/9789264201156-en.

\section{Contact}

Camila de Moraes (camila.demoraes@oecd.org)

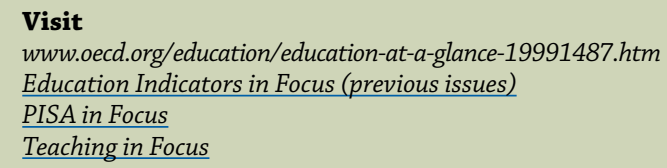

